\title{
Hubungan Nomophobia Dengan Konsentrasi Belajar pada Mahasiswa S1 Keperawatan Stikes Payung Negeri Pekanbaru
}

\author{
Desti Puswati ${ }^{1)}$, Nadia Putri Sari ${ }^{2)}$ \\ ${ }^{1,2}$ Program Studi S1 Keperawatan STIKes Payung Negeri Pekanbaru \\ Email : destipus@ymail.com
}

\section{Diterima: Desember 2021, Diterbitkan: Desember 2021}

\begin{abstract}
Abstrak
Pada masa pandemi Covid 19 pembelajaran dilakukan dengan daring sehingga pelajar maupun mahasiswa sangat mengandalkan perangkat yang mudah untuk dibawa kemana saja yaitu smartphone perkembangan teknologi smartphone yang semakin pesat mempermudah segala aktivitas dan membuat individu khususnya mahasiswa merasa cemas bila jauh dari smartphone kejadian ini disebut nomophobia. Sedangkan normophobia dapat mengganggu konsentrasi belajar. Penelitian dilakukan di kampus Stikes Payung Negeri Pekanbaru dikarenakan berdasarkan hasil wawancara yang dilakukan kepada 10 mahasiswa didapatkan 7 mahasiswa (70\%) mengatakan merasa ketakutan, kecemasan, kegelisahan serta konsentrasi belajarnya terganggu ketika jauh dari ponsel. Tujuan penelitian ini untuk meneliti tentang hubungan nomophobia dengan konsentrasi belajar pada mahasiswa S1 STIKes Payung Negeri Pekanbaru. Penelitian ini menggunakan teknik stratifed random sampling dengan sampel 133 responden. Desain penelitian Corelasi dengan pendekatan cross sectional. Instrumen berupa kuesioner nomophobia diambil dari berbagai sumber dan di lakukan uji validitas di D3 keperawatan Stikes Payung Negeri Pekanbaru. Hasil penelitian normophobia tinggi 60,2 \% dan konsentrasi belajar rendah 48,9\%. P- value 0,00 dimana $\alpha=0,05$ berarti $\mathrm{p}<\alpha$ sehingga hipotesis alternatife (Ha) gagal ditolak, yang berarti ada hubungan Nomophobia dengan tingkat konsentrasi belajar pada mahasiswa.
\end{abstract}

Kata Kunci: Nomophobia, Konsentrasi belajar, Mahasiswa

\begin{abstract}
During Covid-19 pandemic, learning process was carried out online so that most students relied heavily on devices for online learning that were easy to carry anywhere, namely smartphones. the development of smartphone technology, which rapidly increasing, facilitated all activities and making individuals, especially students, feel anxious when away from smartphones. this incident is called nomophobia. normophobia can interfere with learning concentration. The research was carried out at the Stikes Payung Negeri Pekanbaru. based on the results of interviews which was conducted with 10 students; 7 students (70\%) said they felt fear, anxiety, and their learning concentration was disturbed when away from their cellphones. The purpose of this study was to examine the relationship between nomophobia and learning concentration in undergraduate students of STIKes Payung Negeri Pekanbaru. This study used a stratified random sampling technique with a sample of 133 respondents. Correlation research design with cross sectional approach. The instrument in the form of a nomophobia questionnaire was taken from various sources and was tested for validity at the D3 Nursing Stikes Payung Negeri Pekanbaru. The results of the study were high normophobia $60.2 \%$ and low learning concentration $48.9 \%$. P-value 0.00 where $=0.05$ means $p<\alpha$ so that the alternative hypothesis (Ha) fails to be rejected, which means that there is a relationship between Nomophobia and the level of concentration in students' learning.
\end{abstract}

Keywords: Nomophobia, Concentration of learning, Students 


\section{PENDAHULUAN}

Pada masa pandemi Covid 19 pembelajaran dilakukan dengan daring sehingga pelajar maupun mahasiswa sangat mengandalkan perangkat yang mudah untuk dibawa kemana saja yaitu smartphone. Kemudahan dan kenyamanan yang ditawarkan Smartphone, dapat menjadi masalah apabila digunakan secara berlebihan salah satunya adalah Nomophobia yang akhir-akhir ini sedang menjadi salah satu perhatian seluruh dunia. Nomophobia dideskripsikan sebagai ketakutan yang di karenakan ponsel atau internet berada jauh dari jangkauan pemiliknya, Nomophobia juga diartikan sebagai perasaan cemas yang dikarenakan tidak tersedianya perangkat seperti komputer atau perangkat komunikasi virtual, pada defenisi ini lebih berkaitan dengan ponsel, kecanduan semacam itu hadir ketika ada kehilangan kontrol dalam penggunaan smartphone yang tidak bijaksana (Muyana et al., 2017).

Pengguna ponsel pintar di seluruh dunia pada tahun 2020 diperkirakan mencapai 6,1 miliar jiwa. Penggunaan smartphone di Indonesia pada tahun 2018 lebih dari 100 juta orang yang menjadikan negara pengguna smartpone terbesar ke empat di dunia setelah China, India, dan Amerika Serikat dengan usia 18-34 tahun meningkat dari $39 \%$ menjadi $66 \%$ dari tahun 2015-2018, dan dengan usia 50 tahun meningkat $2 \%$ pada tahun 2015 menjadi $13 \%$ pada tahun 2018 (Aziz, 2019).

Lama penggunaan smartphone di kalangan remaja mencapai angka Sembilan jam per harinya. Hal ini lebih lama dibanding waktu yang digunakan pelajar untuk istirahat. Bahkan penggunaan telepon seluler yang diperpanjang menunjukkan bahwa teknologi dapat menyebabkan kecanduan. Kecanduan adalah jenis kebiasan yang tidak terkendali dan tidak sehat (Kowalski, 2014). Semakin sering individu menggunakan smartphone, semakin mereka menjadi ketergantungan pada smartphone (Hong et al., 2014).
Bahkan adanya smartphone juga memiliki efek baru pada perilaku penggunaannya Pengguna smartphone yang berlebihan ini merupakan faktor penyebab meningkatnya depresi, gangguan kecemasan, defisit perhatian, gangguan bipolar, autisme, dan berbagai gangguan perilaku yang terjadi pada anak (Widyawati, Aryanti, 2017).

Penelitian yang dilakukan oleh Sudarji (2017) mengemukakan hasil penelitian sebuah organisasi riset di Inggris menemukan bahwa hampir 53\% pengguna Smartphone di Inggris cenderung menjadi cemas ketika kehilangan smartphone mereka, kehabisan baterai, atau tidak memiliki jangkauan jaringan (Muyana et al., 2017). Penelitian yang dilakukan oleh Mittal dkk tahun 2016 mahasiswa gelisah ketika mereka tidak dapat menghubungi orang yang diinginkan dan ketika mereka lupa membawa ponsel akan timbul kegelisahan, mahasiswa marah karena masalah software $(29.3 \%)$, tidak tersedianya jaringan $(23,4 \%)$, pesan menjengkelkan dan panggilan (22,8\%) (Fajri, 2017).

Berdasarkan survei yang dilakukan

oleh Science Direct mengungkapkan bahwa $25 \%$ dari pengguna Smarpohone yang mayoritas remaja di Asia mengidap Nomobhobia . (Permatasi, 2020). Penelitian yang dilakukan oleh Mulyana, Widyastuti (2018) yang melibatkan 540 siswa SMA di kota Yogyakarta menunjukakan bahwa penggunaan ponsel dikalangan remaja tersebar ditingkat Nomobhobia pada katagori sangat tinggi 5\%, katagori tinggi 31\%, katagori sedang $35 \%$, katagori rendah $24 \%$, dan katagori sangat rendah 5\%. Dilihat dari perkembangannya, remaja sangat terbuka terhadap segala hal baru termasuk perkembangan teknologi smartphone (Permatasi, 2020).

Salah satu dampak dari Nomobhobia terganggunya konsentarasi seseorang, yang dimana konsentasi belajar merupakan kemampuan seorang untuk memusatkan segenap kuatan perhatian 
pada suatu situasi pembelajaran. Unsur motivasi dalam hal ini sangat membantu tumbuhnya proses pemusatan perhatian, di dalam konsentasi ini melibatkan mental secara detail sangat diperlukan. Jika seorang siswa mengalami suatu kesulitan dalam berkomunikasi, jelas belajarnya akan sia-sia karena hanya akan membuang tenaga, waktu, pikiran maupun biaya. Seseorang yang dapat belajar dengan baik adalah orang yang dapat berkomunikasi dengan baik (Thursan, 2013).

Berdasarkan hasil wawancara yang dilakukan kepada 10 mahasiswa S1 Keperawatan Stikes Payung Negeri Pekanbaru didapatkan 7 mahasiswa $(70 \%)$ mengatakan merasa ketakutan, kecemasan, kegelisahan ketika jauh dari ponselnya tersebut, dan 3 mahasiswa (30\%) diantaranya mengatakan biasa- biasa saja dan tidak terlalu memikirkan ketika jauh dari ponselnya tersebut. Berdasarkan fenomena di atas, maka peneliti tertarik untuk meneliti karena mahasiswa S1 keperawatan Stikes Payung Negeri menerapkan belajar online atau daring yang memang memerlukan smartphone dan jaringan internet.

\section{METODE PENELITIAN}

Penelitian dilakukan di Stikes Payung Negeri Pekanbaru program studi S1 Keperawatan. Penelitian dilaksanakan pada bulan Agustus 2020, Populasi yang berjumlah 409 responden. Besar sample 133. Pengumpulan data secara online yang dikirmkan lewat media washapp, menggunakan kuesioner Nomophobia sudah dilakukan uji validitas dan reabilitas di Prodi D3 keperawatan Stikes Payung Negeri Pekanbaru dengan Uji validitas dan reabilitas nilai $r(0,482-0,881)$.Sedangkan kuesioner konsentrasi belajar dari juga telah diuji validitas dan reabilitas dengan $r$ hitung $(0,520-0,610)$ dan $\mathrm{r}$ tabel $(0,44)$. Hasil reliabilitas dari kedua variabel didapatkan $(0,956$ dan 0,950$)$ dan hasil nilai $\mathrm{r}$ instumen nomophobia didapatkan nilai $(0,962-, 966)$ serta nilai $r$ instrument konsentrasi didapatkan nilai (0,945-0,950). Jenis penelitian ini kuantitatif dengan metode korelatif, dengan menggunakan pendekatan cross sectional yaitu suatu penelitian dengan variabel independen Normophobia dan variabel dependen konsentrasi belajar.

\section{HASIL DAN PEMBAHASAN}

Hasil penelitian tentang karakteristik responden umur responden 17 - 25 tahun 133 responden (100\%), Penelitian Firman (2015) bahwa dari60 remaja rentang usia 15- 20 tahun terdapat korelasi positif sebesar 0.343 mengenai kecanduan smarphone terhadap hasil belajar. Jika seseorang tidak kehilangan konsentrasi seseorang akan lebih mudah beralih dari satu objek ke objek lain sehingga seseorang kurang memahami secara keseluruhan. Rentang umur dalam penelitian ini terbanyak adalah 15-25 tahun, yang tergolong pada usia remaja akhir sebagian besar mahasiswa masih belum bisa memanfaatkan waktu yang banyak dengan baik sehingga responden menghabiskan waktunya dengan cara memainkan gadget sampai terjadinya nomophobia.

Penelitian Firman (2015) bahwa dari60 remaja rentang usia 15- 20 tahun terdapat korelasi positif sebesar 0.343 mengenai kecanduan smarphone terhadap hasil belajar. Jika seseorang tidak kehilangan konsentrasi seseorang akan lebih mudah beralih dari satu objek ke objek lain sehingga seseorang kurang memahami secara keseluruhan. Rentang umur dalam penelitian ini terbanyak adalah 15-25 tahun, yang tergolong pada usia remaja akhir sebagian besar mahasiswa masih belum bisa memanfaatkan waktu yang banyak dengan baik sehingga responden menghabiskan waktunya dengan cara memainkan gadget sampai terjadinya nomophobia Perbedaan jenis kelamin juga dapat mempengaruhi kecanduan smarphone.

Karakteristik responden berdasarkan jenis kelamin paling banyak jenis kelamin 
laki-laki 68 responden $(51,1 \%)$. Menurut Paska, Yan (2011) jenis aplikasi smarphone yang digunakan dapat menjadi penyebab individu mengalami kecanduan. Laki- laki dan perempuan menggunakan internet dengan cara yang berbeda, misalnya lakilaki lebih sering mengalami kecanduan terhadap game online, perjudian online, sedangkan perempuan lebih sering mengalami kecanduan terhadap chatting dan belanja online.

Dalam skala dari 25 hingga 100, dengan skor yang lebih tinggi di smartphone tes ketergantungan menunjukkan ketergantungan yang lebih besar, perempuan secara signifikan lebih tergantung pada smartphone daripada lakilaki (berarti ketergantungan smartphone skor: 50,7 vs 56,0 untuk pria dan wanita, masing-masing, p,0,001).Namun, jumlah waktu yang dihabiskan menggunakan ponsel cerdas dan tujuan penggunaan smartphone mempengaruhi ketergantungan smartphone pada pria dan wanita. Khususnya, ketika waktu penggunaan sehari-hari meningkat, ketergantungan smartphone menunjukkan tren yang meningkat. Akhirnya, untuk pria dan wanita, peningkatan ketergantungan smartphone dikaitkan dengan peningkatan skor kecemasan (Lee, 2016).

Tabel 1. Distribusi Frekuensi Responden Berdasarkan Nomophobia di S1 Keperawatan STIKes Payung Negeri Pekanbaru

\begin{tabular}{|c|c|c|c|}
\hline No & Nomophobia & Frequency & $\%$ \\
\hline 1. & Tinggi $60-79$ & 80 & $60.2 \%$ \\
\hline 2. & Sedang 40-59 & 36 & $27.1 \%$ \\
\hline 3. & $\begin{array}{c}\text { Rendah } 20- \\
39\end{array}$ & 17 & $12.8 \%$ \\
\hline & Total & 133 & $100 \%$ \\
\hline
\end{tabular}

Sumber: Analisa data primer 2020

Berdasarkan tabel 1 sebagian besar responden dengan nomophobia tinggi sebanyak 80 responden $(60.2 \%)$ dimana jawaban dari kuesioner responden merasa cemas karena saya tidak dapat terhubung (keep in touch) dengan keluarga dan atau teman sebanyak 83 responden $(62,4 \%)$, Apalagi dengan proses pembelajaran online yang diterapkan dimasa pendemi covid 19, maka mahasiswa akan ketinggalan mata pelajaran apabila tidak terhubung dengan teman2 dan dosen dikampusnya. Sedangkan jawaban responden paling sedikit adalah tidak takut apabila smartphone kehabisan baterai sekitar $6 \%$. Tidak takutan ini karena ketersedian banyak stopkontak aliran listrik diberbagai tempat pada saat ini, serta tersedianya power bank.

Hasil penelitian Rosipa,(2016) didapat $57.0 \%$ mahasiswa memiliki intensitas penggunaan smartphone dalam kategori tinggi dan $64.0 \%$ mahasiswa memiliki nomophobia dalam kategori sedang. Hasil uji analisis menunjukkan terdapat hubungan antara penggunaan smartphone dengan nomophobia ( $\mathrm{p}=$ 0.045). Hasil analisis didapatkan bahwa nomophobia pada mahasiswa dipengaruhi oleh berbagai faktor salah satunya yaitu intensitas penggunaan smartphone.

Berdasarkan penelitian yang dilakukan Pavithra (2015). Siswa yang mengidap nomophobia dipelitian ini dan sekitar $27 \%$ berada pada risiko mengembangkan nomophobia.

Tabel 2. Distribusi Frekuensi Responden Berdasarkan Tingkat Konsentrasi di S1 Keperawatan STIKes Payung Negeri Pekanbaru

\begin{tabular}{lccc}
\hline No & $\begin{array}{c}\text { Tingkat } \\
\text { Konsentrasi }\end{array}$ & Frequency & $\mathbf{\%}$ \\
\hline 1. & Rendah 20-39 & 65 & $48.9 \%$ \\
2. & Sedang 40-59 & 61 & $45.9 \%$ \\
3. & Tinggi $60-79$ & 7 & $5.3 \%$ \\
\hline & Total & $\mathbf{1 3 3}$ & $\mathbf{1 0 0 \%}$ \\
\hline
\end{tabular}

Sumber: Analisa data primer 2020

Berdasarkan tabel 2 konsentrasi belajar responden rendah sebanyak 65 responden (48.9\%). Menurut asumsi peneliti, konsentrasi belajar rendah disebabkan karena responden sedikit yang memperhatikan dosen saat menjelaskan materi pelajaran yaitu $9 \%$, sedangkan apabila dosen memberikan tugas mencatat baru dapat diselesaikan dengan baik sebanyak 50,4 \%.Keadaan ini disebabkan pembelajaran daring dosen tidak dapat 
mengawasi secara langsung dalam satu ruangan sehingga saat perkuliahan tatap muka mahasiswa bisa mendengarkan sambil melakukan tindakan lain, yang menyebabkan konsentrasi belajar rendah. Akan tetapi nomophobia tidak berhubungan lemah dengan prestasi belajar menurut penelitian Qutishat (2020) Studi ini menemukan prevalensi nomophobia yang tinggi dan hubungan yang lemah dengan prestasi akademik.

Tabel 3. Hubungan Nomophobia Dengan

Tingkat Konsentrasi Belajar Pada

Mahasiswa S1 Keperawatan STIKes Payung Negeri Pekanbaru

\begin{tabular}{|c|c|c|c|c|c|c|c|c|c|}
\hline \multirow[t]{2}{*}{ Nomophobia } & \multicolumn{8}{|c|}{ Konstrasi Belajar } & \multirow{2}{*}{$\begin{array}{l}\text { Prespon } \\
\text { Value }\end{array}$} \\
\hline & Rendah & $\%$ & Sedang & $\%$ & Tinggi & $\%$ & Jumlah & $\%$ & \\
\hline Tinggi & 47 & 58,8 & 28 & 35 & 5 & 6,2 & 80 & 100 & \\
\hline Sedang & 4 & 11,1 & 31 & 86.1 & 1 & 2,8 & 36 & 100 & \\
\hline Rendah & 14 & 82,4 & 2 & 11.8 & 1 & 5,9 & 17 & 100 & \\
\hline Total & 65 & 48,9 & 61 & 45.9 & 7 & 5.3 & 133 & 100 & \\
\hline
\end{tabular}

Hasil analisis bivariate 80 responden dengan Nomophobia tinggi dengan tingkat konstrasi belajar rendah sebanyak 47 responden $(58,8 \%)$ dan 17 responden dengan nomophobia rendah dengan konsentrasi rendah sebanyak 14 responden $(82.4 \%)$. Hasil uji statistik diperoleh hasil $p$ value $=0,000$ dimana $\alpha=0,05$ berarti $p<\alpha$ sehingga hipotesis alternatife (Ha) gagal ditolak, yang berarti ada hubungan Nomophobia dengan tingkat konsentrasi belajar pada mahasiswa.

Hasil penelitian Dilla,T (2020), didapatkan adanya hubungan antara kecanduan smartphone dengan kecemasan tanpa smartphone $(\mathrm{P}=0,00)$ (nilai $\mathrm{r}=$ 0,42 ), artinya terdapat hubungan dengan kekuatan sedang dan arah positif. Semakin tinggi kecanduan smartphone semakin mempengaruhi kecemasan tanpa smartphone (nomophobia).

Hal ini sesuai dengan penelitian Pavithra (2015) sekitar 23\% siswa yang merasa mereka kehilangan konsentrasi dan menjadi stress ketika mereka jauh dari ponsel, sebanyak 79 responden (39,5\%).

\section{KESIMPULAN}

1. Hasil penelitian nomophobia tinggi sebanyak 80 responden $(60.2 \%)$

2. Sebagian besar konsentrasi belajar rendah sebanyak 65 responden (48.9\%)

3. Terdapat hubungan antara hubungan nomophobia dengan tingkat konsentrasi belajar pada mahasiswa SI Keperawatan STIKes Payung Negeri Pekanbaru $(\mathrm{p}$ value $=0,000)$.

\section{UCAPAN TERIMAKASIH}

Terimakasih kepada semua yang telah membantu penelitian ini,yaitu seluruh jajaran pimpinan dan staff STIKES Payung Negeri Pekanbaru serta mahasiswa sebagai Presponden.

\section{BAFTAR PUSTAKA}

Aguilera-Manrique, et.al. (2018). The relationship between nomophobia and the distraction associated with smartphone use among nursing students in their clinical practicum. PLoSONE.https://doi.org/10.1371/jo urnal.pone.0202953

Aziz, A. (2019). No Mobile Phone Phobia di Kalangan Mahasiswa Pascasarjana, 06(1), 1-10.

Dilla, T.A (2020) Hubungan Kecanduan Smartphone Dengan Kecemasan (Nomophobia) Pada Mahasiswa Keperawatan Universitas Andalas, http://scholar.unand.ac.id/60088.

Fajri, F. V. (2017). No Hubungan antara penggunaan telepon genggam smartphone dengan nomophobia pada mahasiswa.

Hardianti, F. (2016). Komunikasi Interpersonal Penderita Nomophobia dalam Menjalin Hubungan Persahabartan (Studi pada Mahasiswa Ilmu Komunikasi di Universitas Riau). JOM FISIP Vol.3 No.2:1-4.

Hong, at.al, (2014), Acceptance of Smart Phone by Younger Consumers in Malaysia, Asian Social Science; Vol. 10, No. 6; 2014

Aguilera-Manrique, G., et.al. (2018). The relationship between nomophobia 
and the distraction associated with smartphone use among nursing students in their clinical practicum. PLoS ONE. https://doi.org/10.1371/journal.pone. 0202953

Fajri, F. V. (2017). No Hubungan antara penggunaan telepon genggam smartphone dengan nomophobia pada mahasiswa.

Hardianti, F. (2016). Komunikasi Interpersonal Penderita Nomophobia dalam Menjalin Hubungan Persahabartan (Studi pada Mahasiswa Ilmu Komunikasi di Universitas Riau). JOM FISIP Vol.3 No.2:1-4.

Lee, et.al, (2016), Dependency on Smartphone Use and Its Association with Anxiety in Korea Sage juornal May-Juni, Vol 131, https://journals.sagepub.com/doi/abs/ 10.1177/003335491613100307

Permatasi, I. (2020). Penggunaan bimbingan kelompok teknik self management untuk menurunkan kecenderungan nomophobia (no mobile phone phobia) pada siswa kelas $x$ sma negeri 1 gedongtataan tahun pelajaran 20192020, 2020.

Muyana, S., \& Widyastuti, D. A. (2017). Nomobhobia no-mobile phone phobia penyakit remaja masa kini, 280-287.

Thursan Hakim, Mengatasi Gangguan Konsentrasi, (Jakarta : Puspa Swara, 2013).

Paska, L. M., \& Yan, Z. (2011). Internet addiction in adolescence and emerging adulthood: a comparison between the United States and China. New York: Nova Science,

Permatasi, I. (2020). Penggunaan bimbingan kelompok teknik self management untuk menurunkan kecenderungan nomophobia (no mobile phone phobia) pada siswa kelas $x$ sma negeri 1 gedongtataan tahun pelajaran 20192020, 2020.

Pavithra, et.al (2015) A Study on Nomophobia-Mobile Phone Dependence, among Student of A Medical College In Bangalore, National Journal of Community Medicine,Volume 6,Issue 3, July Sept 2015

Muhammad Anshari, Yabit Alas \& Exzayrani

Sulaiman (2019) Smartphone

addictions and nomophobia among youth, Vulnerable Children and Youth Studies, 14:3, 242247, DOI: $10.1080 / 17450128.2019 .1$ $\underline{614709}$

Muyana, S., \& Widyastuti, D. A. (2017). Nomobhobia no-mobile phone phobia penyakit remaja masa kini, 280-287.

S.Sudarji (2017), Hubungan smartphone dengan Kepercayaan Diri,Psibermetika, Vol 10 No. 1 (2017).

Thursan Hakim, Mengatasi Gangguan Konsentrasi, (Jakarta : Puspa Swara, 2013).

Widyawati,Ariyanti, 2016. Dependency on Smartphone and the Impact on Purcase Behavior in Indonesia, Internationol Journal of Businnes and Economic $2(2)=149$ -

Affairs(IJBEA), 158(2017),https://journal.ubm.ac.id/i ndex.php/psibernetika/article/view/1 041

Qutishat (2020), University students' nomophobia prevalence, sociodemographic factors and relationship with academic performance at a University in Oman, Internasional Juornal Africa Nursing Science Vol 13, 2020, https://www.sciencedirect.com/scien ce/article/pii/S2214139120300834 